\title{
BRONKOPNEUMONIA PADA ANAK USIA 20 BULAN
}

\author{
I Putu Suartawan \\ Fakultas Kedokteran Universitas Islam Al-Azhar \\ Rumah Sakit Umum Daerah Bangli - Bali
}

\begin{abstract}
ABSTRAK
Pneumonia adalah infeksi jaringan paru - paru (Alveoli) yang bersifat akut. Penyebabnya adalah bakteri, virus, jamur, pajanan bahan kimia atau kerusakan fisik dari paru-paru, maupun pengaruh tidak langsung dari penyakit lain. Bakteri yang biasa menyebabkan pneumonia adalah Streptococcus dan Mycoplasma pneumonia, sedangkan virus yang menyebabkan pneumonia adalah Adenoviruses, Rhinovirus, Influenza Virus, Respiratory Syncytial Virus (RSV) dan para Influenza Virus. Terjadinya pneumonia ditandai dengan gejala batuk dan atau kesulitan bernapas seperti napas cepat, dan tarikan dinding dada bagian bawah kedalam. Pada umumnya, pneumonia dikategorikan dalam penyakit menular yang ditularkan melalui udara, dengan sumber penularan adalah penderita pneumonia yang menyebarkan kuman dalam bentuk droplet ke udara pada saat batuk atau bersin. Sampai saat ini, penyakit pneumonia merupakan penyebab utama kematian balita di dunia. Diperkirakan ada 1,8 juta atau $20 \%$ dari kematian anak diakibatkan oleh pneumonia, melebihi kematian akibat AIDS, malaria dan tuberkulosis. Di Indonesia, pneumonia juga merupakan urutan kedua penyebab kematian pada balita setelah diare. Riset Kesehatan Dasar (Riskesdas) melaporkan bahwa kejadian pneumonia sebulan terakhir (period prevalence) mengalami peningkatan pada tahun 2007 sebesar 2,1 \% menjadi 2,7\% pada tahun 2013. Kematian balita yang disebabkan oleh pneumonia tahun 2007 cukup tinggi, yaitu sebesar 15,5\%. Demikian juga hasil Survei Demografi dan Kesehatan Indonesia (SDKI), yang melaporkan bahwa prevalensi pneumonia dari tahun ketahun terus meningkat, yaitu 7,6\% pada tahun 2002 menjadi $11,2 \%$ pada tahun 2007 .
\end{abstract}

Kata Kunci : Bronkopneumonia, Bakteri dan Virus, Penyakit Menular.

\section{PENDAHULUAN}

Insiden penyakit ini pada negara berkembang hampir 30\% pada anak-anak di bawah umur 5 tahun dengan resiko kematian yang tinggi, sedangkan di Amerika pneumonia menunjukkan angka $13 \%$ dari seluruh penyakit infeksi pada anak di bawah umur 2 tahun. Pneumokokus merupakan penyebab utama pneumonia. Pneumokokus dengan serotipe 1 sampai 8 menyebabkan pneumonia pada orang dewasa lebih dari $80 \%$ sedangkan pada anak ditemukan tipe 14, 1, 6 dan 9.

Angka kejadian tertinggi ditemukan pada usia kurang dari 4 tahun dan mengurang dengan meningkatnya umur. Pneumonia lobaris hampir selalu disebabkan oleh pneumococcus, ditemukan pada orang dewasa dan anak besar, sedangkan Bronkopneumonia lebih sering dijumpai pada anak kecil dan bayi.

Menurut buku Pneumonia

Komuniti, Pedoman Diagnosis dan Penatalaksanaan di Indonesia yang dikeluarkan Perhimpunan Dokter Paru Indonesia, 2003 menyebutkan tiga klasifikasi pneumonia.

Berdasarkan klinis dan epidemiologis :

a. Pneumonia Komuniti (communityacquired pneumonia).

b. Pneumonia Nosokomial, (hospitalacquired pneumonia/nosocomial pneumonia).

c. Pneumonia aspirasi.

d. Pneumonia pada penderita Immune 


\section{Compromised.}

Berdasarkan bakteri penyebab :

a. Pneumonia bakteri/tipikal. Dapat terjadi pada semua usia. Beberapa bakteri mempunyai tendensi menyerang seseorang yang peka, misalnya klebsiella pada penderita alkoholik, staphyllococcus pada penderita pasca infeksi influenza. Pneumonia Atipikal disebabkan mycoplasma, legionella, dan chalamydia.

b. Pneumonia virus.

c. Pneumonia jamur, sering merupakan infeksi sekunder. Predileksi terutama pada penderita dengan daya tahan lemah (immunocompromised).

Berdasarkan predileksi infeksi :

a. Pneumonia lobaris, pneumonia yang terjadi pada satulobus (percabangan besar dari pohon bronkus) baik kanan maupun kiri.

b. Pneumonia bronkopneumonia, pneumonia yang ditandai bercakbercak infeksi pada berbagai tempat di paru. Bisa kanan maupun kiri yang disebabkan virus atau bakteri dan sering terjadi pada bayi atau orang tua.

c. Pneumonia interstisial.

Bila pertahanan tubuh tidak kuat maka mikroorganisme dapat melalui jalan nafas sampai ke alveoli yang menyebabkan radang pada dinding alveoli dan jaringan sekitarnya. Setelah itu mikroorganisme tiba di alveoli mementuk suatu proses peradangan yang meliputi empat stadium, yaitu :

\section{Stadium I (4 - 12 jam pertama/kongesti)}

Disebut Hiperemia, mengacu pada respon peradangan permulaan yang berlangsung pada daerah baru yang terinfeksi. Hal ini ditandai dengan peningkatan aliran darah dan permeabilitas kapiler di tempat infeksi. Hiperemia ini terjadi akibat pelepasan mediator-mediator peradangan dari sel-sel mast setelah pengaktifan sel imun dan cedera jaringan. Mediator-mediator tersebut mencakup histamin dan prostaglandin. Degranulasi sel mast juga mengaktifkan jalur komplemen. Komplemen bekerja sama dengan histamin dan prostaglandin untuk melemaskan otot polos vaskuler paru dan peningkatan permeabilitas kapiler paru. Hal ini mengakibatkan perpindahan eksudat plasma ke dalam ruang interstitium sehingga terjadi pembengkakan dan edema antar kapiler dan alveolus. Penimbunan cairan di antara kapiler dan alveolus meningkatkan jarak yang harus ditempuh oleh oksigen dan karbondioksida maka perpindahan gas ini dalam darah paling berpengaruh dan sering mengakibatkan penurunan saturasi oksigen hemoglobin.

\section{Stadium II (48 jam berikutnya)}

Disebut Hepatisasi Merah, terjadi sewaktu alveolus terisi oleh sel darah merah, eksudat dan fibrin yang dihasilkan 
oleh penjamu (host) sebagai bagian dari reaksi peradangan. Lobus yang terkena menjadi padat oleh karena adanya penumpukan leukosit, eritrosit dan cairan, sehingga warna paru menjadi merah dan pada perabaan seperti hepar, pada stadium ini udara alveoli tidak ada atau sangat minimal sehingga anak akan bertambah sesak. Stadium ini berlangsung sangat singkat, yaitu selama 48 jam.

\section{Stadium III (3 - 8 hari)}

Disebut Hepatisasi Kelabu yang terjadi sewaktu sel-sel darah putih mengkolonisasi daerah paru yang terinfeksi. Pada saat ini endapan fibrin terakumulasi di seluruh daerah yang cedera dan terjadi fagositosis sisa-sisa sel. Pada stadium ini eritrosit di alveoli mulai diresorbsi, lobus masih tetap padat karena berisi fibrin dan leukosit, warna merah menjadi pucat kelabu dan kapiler darah tidak lagi mengalami kongesti.

\section{Stadium IV (7 - 12 hari)}

Disebut juga stadium resolusi yang terjadi sewaktu respon imun dan peradangan mereda, sisa-sisa sel fibrin dan eksudat lisis dan diabsorbsi oleh makrofag sehingga jaringan kembali ke strukturnya semula.

Penyakit pneumonia dapat dicegah dengan menghindari kontak dengan penderita atau mengobati secara dini penyakit - penyakit yang dapat menyebabkan terjadinya pneumonia ini. Selain itu hal-hal yang dapat dilakukan adalah dengan meningkatkan daya tahan tubuh kaitan terhadap berbagai penyakit saluran nafas seperti : cara hidup sehat, makan makanan bergizi dan teratur, menjaga kebersihan, beristirahat yang cukup, rajin berolahraga, dan lain-lain. Melakukan vaksinasi juga diharapkan dapat mengurangi kemungkinan terinfeksi antara lain :

- Vaksinasi Pneumokokus

- Vaksinasi H. Influenza

- Vaksinasi Varisela yang dianjurkan pada anak dengan daya tahan tubuh rendah

- Vaksin influenza yang diberikan pada anak sebelum anak sakit.

Dengan penggunaan antibiotik yang tepat dan cukup, mortalitas dapat diturunkan sampai kurang dari $1 \%$. Anak dalam keadaan malnutrisi energi protein dan yang datang terlambat menunjukkan mortalitas yang lebih tinggi.

Pada pneumonia yang disebabkan oleh Staphylococcus Aureus, angka kesembuhan penderita mengalami kemajuan besar dengan penatalaksanaan sekarang, angka mortalitas berkisar dari 10 - 30\% dan bervariasi dengan lamanya sakit yang dialami sebelum penderita dirawat, umur penderita, pengobatan yang memadai serta adanya penyakit yang menyertai.

\section{INVESTIGASI}

\section{Anamesis}


Riwayat penyakit sekarang: pasien datang ke IGD RSU Bangli diantar keluarga dengan keluhan sesak. Keluarga mengatakan sesak dirasakan sejak pukul 04.00 pagi sebelum masuk rumah sakit. Sesak yang dialami membuat pasien menjadi rewel dan tidak dapat tidur. Ibu pasien mengatakan awalnya pasien mengalami batuk dan pilek sejak 4 hari sebelum masuk rumah sakit. Batuk disertai dahak namun tidak dapat keluar. Dari hidung keluar cairan berwarna bening dan diikuti oleh demam. Pada saat diukur dirumah, suhu badan pasien mencapai $38^{\circ} \mathrm{C}$. sebelumnya pasien pernah dibawa ke Puskesmas dan mendapat obat penurun panas, antibiotik, dan obat puyer. Keluhan lain seperti mual dan muntah disangkal, BAB (+) normal, BAK (+) normal, nafsu makan menurun, terjadi penurun berat badan.

\section{Riwayat Penyakit Sebelumnya}

Pasien pernah mengalami keluhan seperti ini sebelumnya pada tahun 2018 dan sempat dirawat di rumah sakit. Riwayat penyakit lain seperti penyakit jantung, asma, disangkal oleh keluarga pasien.

\section{Riwayat Penyakit Keluarga}

Riwayat anggota keluarga mengalami keluhan serupa disangkal. Riwayat penyakit Hipertensi, Diabetes Mellitus, Penyakit Jantung, Asma, Tuberculosis, di keluarga disangkal.

\section{Riwayat Alergi}

Keluarga pasien menyangkal pasien memiliki riwayat alergi makanan, obatobatan, dan suhu.

\section{Riwayat Sosial}

Ayah pasien tidak merokok, dan di lingkungan tempat tinggal pasien tidak ada yang merokok. Pasien merupakan anak ke 2 dari 2 bersaudara.

\section{Riwayat Pengobatan}

Untuk keluhannya saat ini pasien sebelumnya sempat berobat ke puskesmas, dan diberikan obat paracetamol sirup $3 \times 120 \mathrm{mg}$, eritromicin sirup 3x100 mg, dan obat puyer yang diminum 3 kali sehari.

\section{Riwayat Imunisasi}

- DPT (+) jumlah: 4 kali usia: 2, 3, 4, 18 bulan.

- $\operatorname{BCG}(+) \quad$ jumlah: 1 kali usia: 2 bulan.

- Campak (+) jumlah: 1 kali usia: 9 bulan.

- Hepatitis B (+) jumlah: 4 kali usia: $0,2,3,4$ bulan.

- Polio (+) jumlah: 4 kali usia: $0,2,3,4$ bulan.

- JE (+) jumlah: 1 kali usia: 12 bulan.

- MR (-) jumlah: 0 kali

\section{Riwayat Kelahiran}

Pasien lahir normal di Rumah Sakit, persalinan di tolong oleh dokter. Bayi langsung menangis, usia kehamilan cukup bulan, bayi tunggal, presentasi kepala, dengan berat badan lahir 3000 gram, 
panjang badan $50 \mathrm{~cm}$, lingkar kepala 43 $\mathrm{cm}$, segera menangis.

\section{Riwayat Nutrisi}

Usia 0-6 bulan : ASI eksklusif

Usia 6 bulan : bubur susu

Usia 12 bulan : nasi tim

Usia 14 bulan :makanan dewasa

\section{Riwayat Tumbuh Kembang}

- Menegakkan kepala : 2 bulan

- Membalikkan badan:4 bulan

- Duduk : 6 bulan

- Merangkak :8 bulan

- Berdiri : 10 bulan

- Berjalan : 12 bulan

- Riwayat operasi : tidak ada

- Riwayat transfuse : tidak ada

\section{PEMERIKSAAN FISIK}

\section{Tanda Vital}

- Keadaan umum : tampak sakit sedang

- Kesadaran : compos mentis

- GCS : E4V5M6

- Tekanan darah $:-$

- Nadi : $124 \mathrm{x} /$ menit

- Suhu $: 36,7^{0} \mathrm{C}$

- Respirasi : 50x/menit

- $\mathrm{SpO} 2$ :97\% tanpa O2

\section{Status Gizi Menurut WHO}

- Umur : 20 bulan

- Jenis kelamin : perempuan

- Berat badan $: 10,4 \mathrm{~kg}$

- Panjang badan $: 84 \mathrm{~cm}$

- Berat badan ideal : $11 \mathrm{~kg}$
- Berat badan / umur :-2 SD - 2SD

- Panjang badan / umur : -2 SD - 2 SD

- Berat badan / panjang badan : -2 SD $2 \mathrm{SD}$

- Status gizi : 94,5\% (Gizi baik)

\section{Status Generalis}

- Kepala : normocephali

- Mata : konjungtiva anemis $(+/+)$, sclera ikterik (-/-), reflek pupil $(+/+)$ isokor, mata cowong (-)

- THT : nafas cuping hidung(-), rhinorea (-), tonsil T1-T1 kesan tenang, faring hiperemis (-)

- Leher : pembesaran kelenjar getah bening (-), deviasi trachea (-),

\section{Thorax}

\section{Pulmo}

- Inspeksi : pergerakan dinding dada simetris, massa (-), retraksi dinding dada (+) subternal, dan intercostal, napas bronkial

- Palpasi : nyeri tekan (-), vocal fremitus sama kiri dan kanan

- Perkusi : sonor di seluruh lapang paru

- Auskultasi : vesicular (+/+), ronkhi $(+/+)$, wheezing $(+/+)$

Cor

- Inspeksi : iktus kordis tidak tampak

- Palpasi : iktus kordis tidak teraba

- Perkusi : batas atas : ICS 2 garis sternalis sinistra batas kanan : 
ICS 5 garis paraternal dextra batas kiri : ICS 5 garis midclavikula sinistra.

- Auskultasi : S1S2 tunggal, regular, murmur (-)

\section{Abdomen}

- Inspeksi : datar, massa (-), gerakan sesuai nafas

- Auskultasi : bising usus (+) normal.

- Perkusi : timpani (+) di seluruh lapang abdomen.

- Palpasi : massa (-), nyeri tekan (), pembesaran organ (-).

- Ekstremitas : akral hangat (+), edema $(-)$, sianosis (-).

\section{RESUME}

Bayi perempuan usia 20 bulan datang dengan keluhan sesak, yang dirasakan sejak pukul 04.00 pagi sebelum masuk rumah sakit. Sesak yang dialami membuat pasien menjadi rewel dan tidak dapat tidur. Awalnya pasien mengalami batuk dan pilek sejak 4 hari sebelum masuk rumah sakit. Batuk disertai dahak namun tidak dapat keluar. Dari hidung keluar cairan berwarna bening dan diikuti oleh demam. Pada saat diukur dirumah, suhu badan pasien mencapai $38^{\circ} \mathrm{C}$. Pasien pernah dibawa ke Puskesmas dan mendapat obat penurun panas, antibiotik, dan obat puyer. BAB (+) normal, BAK (+) normal, nafsu makan menurun, terjadi penurun berat badan. Pasien pernah mengalami keluhan seperti ini sebelumnya pada tahun 2018 dan sempat dirawat di rumah sakit. Pada pemeriksaan fisik didapatkan keadaan umum pasien tampak sakit sedang, kesadaran compos mentis, GCS: E4V5M6, Nadi 124x/menit, Suhu $36,7^{\circ} \mathrm{C}$, laju respirasi 50x/menit, $\mathrm{SpO} 2$ : 97\% tanpa O2, konjungtiva anemis (+/+),retraksi dinding dada (+) intercostal, napas bronkial, suara napas vesicular $(+/+)$, ronkhi $(+/+)$, wheezing $(+/+)$.

\section{PEMERIKSAAN PENUNJANG}

Tabel 01. Darah Lengkap tanggal 12 April 2019

\begin{tabular}{|l|l|l|l|}
\hline Indicator & Hasil & $\begin{array}{l}\text { Normal } \\
\text { Range }\end{array}$ & Satuan \\
\hline WBC & 23,6 & $3,5-10,0$ & $10^{\wedge} 9 / \mathrm{L}$ \\
\hline LYM & 5,5 & $0,5-5,0$ & $10^{\wedge} 9 / \mathrm{L}$ \\
\hline LYM\% & 23,4 & $\begin{array}{l}20,0- \\
50,0\end{array}$ & $\%$ \\
\hline MID & 1,1 & $0,1-1,5$ & $10^{\wedge} 9 / \mathrm{L}$ \\
\hline MID\% & 4,7 & $2,0-15,0$ & $\%$ \\
\hline GRA & 17,0 & $1,2-8,0$ & $10^{\wedge} 9 / \mathrm{L}$ \\
\hline GRA\% & 71,9 & $\begin{array}{l}35,0- \\
80,0\end{array}$ & $\%$ \\
\hline HGB & 10,8 & $\begin{array}{l}11,5- \\
16,5\end{array}$ & $\mathrm{~g} / \mathrm{dL}$ \\
\hline MCH & 25,0 & $\begin{array}{l}25,0- \\
35,0\end{array}$ & $\mathrm{pg}$ \\
\hline MCHC & 34,8 & $\begin{array}{l}31,0- \\
38,0\end{array}$ & $\mathrm{~g} / \mathrm{dL}$ \\
\hline RBC & 4,33 & $\begin{array}{l}3,50- \\
5,50\end{array}$ & $10^{\wedge} 12 / \mathrm{L}$ \\
\hline MCV & 71,8 & $\begin{array}{l}75,0- \\
100,0\end{array}$ & $\mathrm{fl}$ \\
\hline HCT & 31,1 & $\begin{array}{l}35,0- \\
55,0\end{array}$ & $\%$ \\
\hline RDWa & 52,3 & $\begin{array}{l}30,0- \\
150,0\end{array}$ & $\mathrm{fl}$ \\
\hline RDW\% & 14,6 & $\begin{array}{l}11,0- \\
16,0\end{array}$ & $\%$ \\
\hline PLT & 467 & $150-400$ & $10^{\wedge} 9 / \mathrm{L}$ \\
\hline MPV & 6,3 & $8,0-11,0$ & $\mathrm{fl}$ \\
\hline PDWa & 8,9 & $0,1-99,9$ & $\mathrm{fl}$ \\
\hline PCT & 0,29 & $\begin{array}{l}0,01- \\
9,99\end{array}$ & $\%$ \\
\hline P-LCR & 5,1 & $0,1-99,9$ & $\%$ \\
\hline
\end{tabular}


Tabel 02. Gula Darah Sewaktu tanggal 12 April 2019.

\begin{tabular}{|l|l|c|l|}
\hline Indicator & Hasil & $\begin{array}{c}\text { Normal } \\
\text { Range }\end{array}$ & Satuan \\
\hline GDS & 73 & $75-115$ & $\mathrm{mg} / \mathrm{dL}$ \\
\hline
\end{tabular}

Rontgen Thorax tangggal 12 April 2019

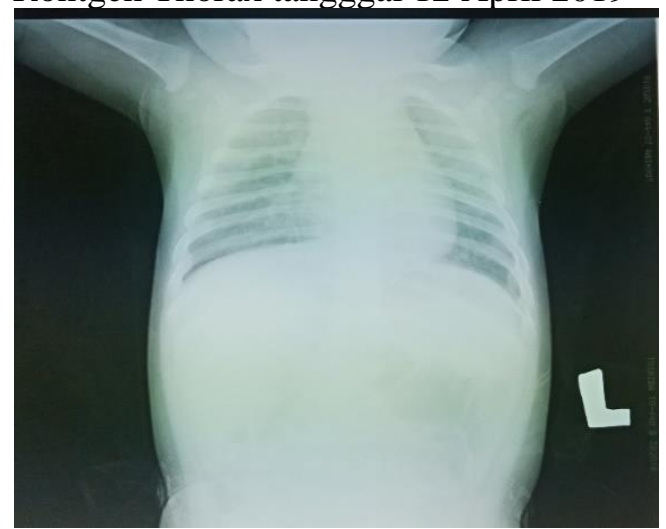

Gambar 01. Rontgen Thorax

- Bercak infiltrat di kedua paru, terutama kanan.

- Tidak tampak pemadatan hilus.

- Cor dalam batas normal.

- Aorta tidak dilatasi.

- Kedua sinus lancip dan diafragma kesan baik.

- Tulang rongga dada kesan intak.

Kesan: gambaran bisa mendukung bronchopneumonia.

\section{DIAGNOSIS KERJA}

Bronkopneumonia + Anemia Hipokromik Mikrositer.

\section{PENATALAKSANAAN}

- IVFD D5\% 1/4 NS 12 tpm makro

- Ceftriaxone 2x500 mg IV

- Dexamethasone 3 x 1/3 amp

- Sanmol flash 10cc @8 jam

- Ambroxol syrup $3 \times 1 / 2$ cth
- Nebul Ventolin 1/2 resp @ 8 jam

- Monitor vital sign dan keluhan

PEMBAHASAN

Pada kasus ini, pasien bayi perempuan usia 20 bulan. Diagnosis bronkopneumonia didapatkan atas dasar anamnesis pemeriksaan fisik, dan pemeriksaan penunjang. Pada teori, bronkopneumonia adalah inflamasi pada bronkiolitis dan parenkim paru dengan gejala trias pneumonia berupa sesak, batuk atau pilek, demam, dan didapatkan ronchi serta wheezing pada paru apabila sudah terjadi inflamasi pada bronkiolus. Berdasarkan anamnesis pasien datang dengan keluhan sesak, yang dirasakan sejak pukul 04.00 pagi sebelum masuk rumah sakit. Sesak yang dialami membuat pasien menjadi rewel dan tidak dapat tidur. Awalnya pasien mengalami batuk dan pilek sejak 4 hari sebelum masuk rumah sakit. Batuk disertai dahak namun tidak dapat keluar. Dari hidung keluar cairan berwarna bening dan diikuti oleh demam. Pada saat diukur dirumah, suhu badan pasien mencapai $38^{\circ} \mathrm{C}$. Pasien pernah dibawa ke Puskesmas dan mendapat obat penurun panas, antibiotik, dan obat puyer. BAB (+) normal, BAK (+) normal, nafsu makan menurun, terjadi penurun berat badan. Pasien pernah mengalami keluhan seperti ini sebelumnya pada tahun 2018 dan sempat dirawat di rumah sakit. Pada pemeriksaan fisik didapatkan keadaan 
umum pasien tampak sakit sedang, kesadaran compos mentis, GCS: E4V5M6, Nadi 124x/menit, Suhu $36,7^{\circ} \mathrm{C}$, laju respirasi 50x/menit, $\mathrm{SpO}$ : 97\% tanpa O2, konjungtiva anemis $(+/+)$, retraksi dinding dada $(+)$ intercostal, napas bronkial, suara napas vesicular $(+/+)$, ronkhi $(+/+)$, wheezing $(+/+)$.

Pada pemeriksaan fisik pasien dengan pneumonia, pada inspeksi dapat ditemukan adanya peningkatan frekuensi nafas, nafas cuping hidung, retraksi otot (epigastrik, interkostal, suprasternal), pada auskultasi paru ditemukan adanya crackles. Sedangkan pada kasus, pada pemeriksaan fisik juga ditemukan adanya frekuensi napas yang meningkat dan terlihat retraksi pada daerah intercostalis pada kedua regio thorax pasien, pada auskultasi ditemukan suara ronkhi dan wheezing pada seluruh lapang paru pasien.

Hasil pemeriksaan rontgen thorax pada kasus pneumonia pada umumnya ditemukan adanya gambaran infiltrate pada lapang paru, dan pada pemeriksaan darah lengkap ditemukan peningkatan sel darah putih (leukositosis). Pada kasus dilakukan pemeriksaan rontgen thoraks AP dan didapatkan adanya bercak-bercak infiltrate pada kedua lapang paru, terutama kanan, dan kesan mendukung bronkopneumonia. Pada pemeriksaan darah lengkap didapatkan hasil yaitu peningkatan WBC sebesar 23,600.

Penatalaksanaan pada pasien
Penatalaksanaan pada pasien dengan pneumonia dapat berupa penatalaksanaan secara suportif yaitu dengan pemberian $\mathrm{O}_{2}$ dan nutrisi parenteral. Diberikan pula terapi antibiotik yang diberikan secara empiris. Pada usia 3 bulan-5 tahun diberikan antibiotic yaitu golongan ampisilin + kloramfenikol, dan ditambahkan makrolid jika tidak berespon dengan ampisilin + kloramfenikol. Pengobatan pada kasus diberikan terapi suportif berupa pemasangan IV line dengan cairan infus D5 $1 / 4$ NS yang diberikan dalam 12 tetes permenit dengan tetesan makro, diberikan antibiotic sebagai terapi kausatif yaitu berupa Ceftriaxone 2 x $500 \mathrm{mg}$, diberikan dexamethason 3 x 1/3 amp sebagai antiinflamasi, setelah itu diberi obat-obatan simptomatik untuk mengatasi keluhan yang dirasakan pasien seperti paracetamol flash untuk meredakan demam, ambroxol untuk mengencerkan dahak, dan diberikan nebul ventolin agar terjadinya bronco dilatasi.

Simpulan, dari hasil anamnesis, pemeriksaan fisik, dan pemeriksaan penunjang, pasien di diagnosis dengan bronkopneumonia. Tatalaksana yang diberikan berupa pengobatan suportif, pemberian antibiotik, dan simptomatis. Prognosis pada kasus ini baik, umumnya penderita bahkan dapat sembuh spontan dalam 2-3 minggu. Apalagi jika dilihat berdasarkan gambaran klinis selama perawatan pasien sudah sangat membaik. 
Keluhan juga mulai berkurang perlahan.

Hal ini ditandai dengan batuk dan sesak yang sudah mulai berkurang dan demam yang turun dalam masa perawatan. Prognosis penderita ini adalah dubia ad bonam untuk quo ad vitam dan functionam.

\section{DAFTAR PUSTAKA}

Reinhard V. Putz, Reinhard Pabst. Atlas AnatomiManusiaSobottaJilid 2. Edisi 21. BukuKedokteran EGC. Jakarta : 2000. Hal 99.

Guyton, Hall. Buku Ajar FisiologiKedokteran.

BukuKedokteran EGC. Jakarta : 1997. Hal 633.

O’Brodovich Hugh M, Haddad Gabriel G. Kendig's Disorder of the Respiratory Tract in Children: "The Functional Basis of Respiratory Pathology and Disease", Sixth Edition. WB. Saunders Company Philadelphia, London, Toronto, Montreal, Sydney, Tokyo. 1998.

Pasterkamp Hans. Kendig's Disorder of the Respiratory Tract in Children :"The History and Physical Examination", Sixth Edition. WB. Saunders Company Philadelphia, London, Toronto, Montreal, Sydney, Tokyo. 1998.

Correa Armando.G, Starke Jeffrey R. Kendig's Disorder of the Respiratory Tract in Children: "Bacterial Pneumoniasi", Sixth Edition. WB. Saunders Company Philadelphia, London, Toronto, Montreal, Sydney, Tokyo. 1998.

Konsensus Pneumonia.

BagianPulmonologi FKUI/RSUP Persahabatan. Jakarta : 2000.

Pedoman Terapi Ilmu Kesehatan Anak, Unpad. Bandung : 2005.
Sectish Theodore C, Prober Charles G. Nelson Textbook of Pediatrics: "Pneumonia". Edisi ke-17. Saunders. 2004.

Pusponegoro HD, dkk. Standar Pelayanan Medis Kesehatan Anak. Ikatan Dokter Anak Indonesia: Jakarta. 2004.

Hasan R, dkk. Ilmu Kesehatan Anak. Fakultas Kedokteran Universitas Indonesia: Jakarta. 2002.

Mansjoer A, dkk. Kapita Selekta Kedokteran. Media Aesculapius Fakultas Kedokteran Universitas Indonesia: Jakarta. 2000.

Price SA, Wilson LM, 1995, Pathophysiology: Clinical Concepts of Disease Processes (Patofisiologi: KonsepKlinis Proses-Prose Penyakit), Edisi 4, Penerbit EGC, Jakarta, hal: 709-712

Behrman RE, Vaughan VC.Nelson Ilmu Kesehatan Anak, Bagian II, Edisi 12, Penerbit EGC, Jakarta, 2000, hal: 617-628. 